\title{
Substituent Effects on Pyrid-2-yl Ureas toward Intramolecular Hydrogen Bonding and Cytosine Complexation
}

\author{
Chia-Hui Chien, Man-kit Leung,* J en-Kuan Su, Gene-Hsiang Li, Yi-Hung Liu, and Yu Wang \\ Department of Chemistry, National Taiwan University, Taipei, Taiwan 106, Republic of China \\ mkleung@ntu.edu.tw \\ Received October 28, 2003
}

\begin{abstract}
E quilibria between two conformational isomers of pyrid-2-yl ureas, the $(E, Z)$ and $(Z, Z)$ forms, have been studied in $D M F-d_{7}$ at $-70{ }^{\circ} \mathrm{C}$. M ost of them show a small preference for the $(E, Z)$ form with an equilibrium constant $K_{i}$ around 1-2. However, the $K_{i}$ value for 1-methyl-2-(3-(pyrid-2-yl)ureido)pyridinium iodide (12) was found to be $14.2 \pm 1.2$. That is 1 order of magnitude larger than those of the others, which indicates that the positively charged 1-methylpyridinium-2-yl substituent would facilitate the $(E, Z)$ form formation. Pyrid-2-yl ureas bind cytosine in DMF $-d_{7}$ with binding constants $\mathrm{K}_{\mathrm{B}}$ ranging from 30 to $1700 \mathrm{M}^{-1}$. Electron withdrawing substituents, such as the $4-\mathrm{O}_{2} \mathrm{NC}_{6} \mathrm{H}_{4}-$ or 1-methylpyridinium-4-yl substituent, preferentially facilitate the intermolecular cytosine complexation with large binding constants.
\end{abstract}

\section{Introduction}

It has long been known that hydrogen bonds are responsible for the intermolecular and intramolecular order in carbohydrates, ${ }^{1}$ proteins, ${ }^{2}$ and nucleic acids. ${ }^{3}$ Many artificial receptors that employ hydrogen bond centers or arrays as the recognition and binding elements have been designed and synthesized. ${ }^{4}$ In particular, molecules containing appropriate hydrogen arrays have recently been used to harpoon the unpaired or bulged bases in duplex DNA, which arise either from replication error or from recombination of single stranded DNAs that are not completely complementary to each other. For example, 2-acylamino-1,8-naphthyridine derivatives have been used to recognize single guanine bulges or to induce DNA hairpins. ${ }^{5}$ Since our interest in the chemistry of organic urea continues, ${ }^{6}$ we have examined the possibility of using pyrid-2-yl urea as a receptor to recognize cytosine

(1) (a) Wong, C.-H. Acc. Chem. Res. 1999, 32, 376. (b) Poveda, A.; J ime'nez-Barbero, J . Chem. Soc. Rev. 1998, 27, 133.

(2) (a) Peczuh, M. W.; Hamilton, A. D. Chem. Rev. 2000, 100, 2479. (b) Cheng, R. P.; Gellman, S. H.; DeGrado, W. F. Chem. Rev. 2001, 101, 3219. (c) Venkatraman, J .; Shankaramma, S. C.; Balaram, P. Chem. Rev. 2001, 101, 3131.

(3) (a) Majumdar, A.; Patel, D. J . Acc. Chem. Res. 2002, 35, 1. (b) Pirrung, M. C. Angew. Chem., Int. Ed. 2002, 41, 1276. (c) Capila, I.; Linhardt, R. J. Angew. Chem., Int. Ed. 2002, 41, 390. (d) Niemeyer, C. M. Angew. Chem., Int. Ed. 2001, 40, 4128.

(4) (a) Zhu, P.; Kang, H.; Facchetti, A.; Evmenenko, G.; Dutta, P.; Marks, T. J . J . Am. Chem. Soc. 2003, 125, 11496. (b) Hunter, C. A.; Low, C. M. R.; Vinter, J. G.; Zonta, C. J. Am. Chem. Soc. 2003, 125, 9936. (c) Al-Sayah, M. H.; Branda, N. R. Org. Lett. 2002, 4, 881. (d) Archer, E. A.; Sochia, A. E.; Krische, M. J . Chem.-Eur. J . 2001, 7, 2049. (e) Mancin, F.; Chin, J . J . Am. Chem. Soc. 2002, 124, 10946. (f) Pedireddi, V. R.; Ranganathan, A.; Ganesh, K. N. Org. Lett. 2001, 3, 99. (g) Söntjens, S. H. M.; Sijbesma, R. P.; van Genderen, M. H. P.; Meijer, E. W. J. Am. Chem. Soc. 2000, 122, 7487. (h) Archer, E. A.; Goldberg, N. T.; Lynch, V.; Krische, M.J .J . Am. Chem. Soc. 2000, 122, 5006. (i) Bisson, A. P.; Carver, F. J .; Eggleston, D. S.; Haltiwanger, R. C.; Hunter, C. A.; Livingstone, D. L.; McCabe, J . F.; Rotger, C.; Rowan, A. E. J. Am. Chem. Soc. 2000, 122, 8856.

(5) (a) Smith, E. A.; Kyo, M.; Kumasawa, H.; Nakatani, K.; Saito, I.; Corn, R. M. J . Am. Chem. Soc. 2002, 124, 6810. (b) Nakatani, K.; Sando, S.; Saito, I. J . Am. Chem. Soc. 2000, 122, 2171.
(Scheme 1), an important hydrogen bonding unit for DNA binding. ${ }^{7}$ Pyrid-2-yl ureas are known to have significant biological activity in various dimensions, including anticancer properties. ${ }^{8}$ Although the $(Z, Z)$ form of pyrid-2yl urea contains an ADD hydrogen bonding array ${ }^{9}$ that is complementary to the array of cytosine, their binding is hindered by a competitive intramolecular hydrogen bond between the pyridyl nitrogen and the ureido hydrogen that stabilizes the pyrid-2-yl urea in the $(E, Z)$ form. ${ }^{10,11}$ To make the binding more effective, substituents that could preferentially enhance the cytosine complexation over the intramolecular hydrogen bonding interaction are desired.

\section{Results and Discussion}

Synthesis of the Pyrid-2-yl Ureas. To understand the substituent effects, we explored a series of substituted

(6) (a) Chen, J .-A.; Lai, J .-L.; Lee, G. H.; Wang, Y.; Su, J . K.; Yeh, H.-C.; Lin, W.-Y.; Leung, M.-k. Org. Lett. 2001, 3, 3999. (b) Liao, C.F.; Lai, J .-L.; Chen, J .-A.; Chen, H.-T.; Cheng, H.-L.; Her, G.-R.; Su, J . K.; Wang, Y.; Lee, G. H.; Leung, M.-k.; Wang, C.-C. J . Org. Chem. 2001, 66, 2566. (c) Lai, J .-L.; Leung, M.-k.; Lee, G. H. J . Org. Chem. 1996, 61, 8364.

(7) (a) Rajeev, K. G.; Maier, M. A.; Lesnik, E. A.; Manoharan, M. Org. Lett. 2002, 4, 4395. (b) Glaser, R.; Lewis, M. Org. Lett. 1999, 1 273. (c) Sakurai, K.; Shinkai, S. J. Am. Chem. Soc. 2000, 122, 4520.

(8) (a) Pappas, I. S.; Niopas, I.; Tsiftsoglou, A. S. Anti-Cancer Drug Des. 1992, 7, 153. (b) Honma, T.; Hayashi, K.; Aoyama, T.; Hashimoto, N.; Machida, T.; Fukasawa, K.; I wama, T.; Ikeura, C.; I kuta, M.; Suzuki-Takahashi, I.; I wasawa, Y.; Hayama, T.; Nishimura, S.; Morishima, H. J . Med. Chem. 2001, 44, 4615. (c) Hocquet, A.; Tohier, J . J . Chem. Educ. 1994, 71, 1092. (d) Bruce, M. I.; Zwar, J . A. Proc. R. Soc. London, Ser. B 1966, 165, 245.

(9) Lüning, U.; Kühl, C.; U phoff, A. Eur. J . Org. Chem. 2002, 4063.

(10) (a) Corbin, P. S.; Zimmerman, S. C.; Thiessen, P. A.; Hawryluk, N. A.; Murray, T. J . J . Am. Chem. Soc. 2001, 123, 10475. (b) Singha N. C.; Sathyanarayana, D. N. J . Chem. Soc., Perkin Trans. 21997 157. (c) Sudha, L. V.; Sathyanarayana, D. N. J . Mol. Struct. 1985, 131, 253. (d) Sudha, L. V.; Sathyanarayana, D. N. J . Mol. Struct. 1984, 125, 89. (e) Camilleri, P.; Odell, B.; Rzepa, H. S.; Sheppard, R. N. Chem. Commun. 1988, 1132. (f) Ge, Y.; Miller, L.; Ouimet, T.; Smith, D. K. J. Org. Chem. 2000, 65, 8831.

(11) J iménez Blanco, J . L.; Benito, J . M.; Ortiz Mellet, C.; García Fernández, J. M. Org. Lett. 1999, 1, 1217. 
SCHEME 1

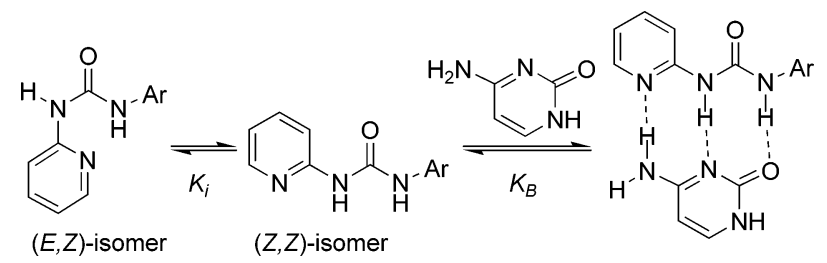

\section{SCHEME 2}
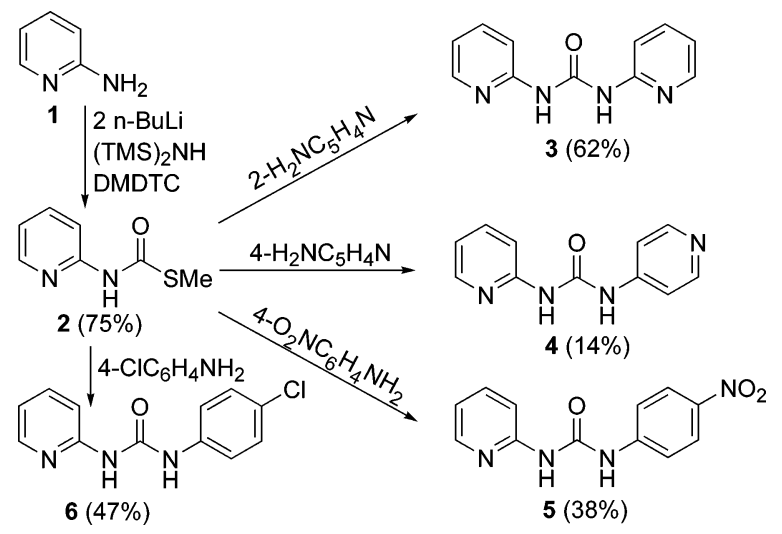

SCHEME 3

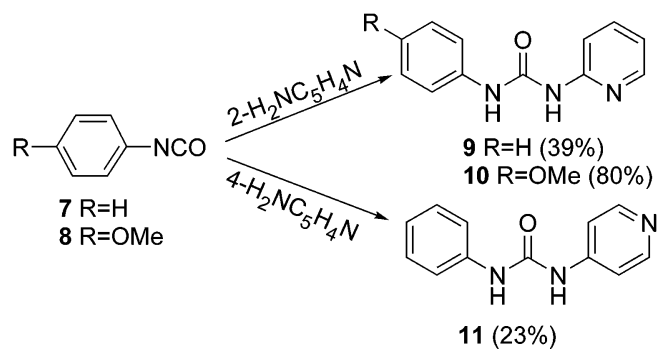

\section{SCHEME 4}

$$
\text { (2) }
$$

pyrid-2-yl ureas 3-6, 9, 10, 12, and $\mathbf{1 3}$. The syntheses of these compounds are summarized in Schemes 2-4. Since the corresponding isocyanate precursor of 3-6 is unavailable commercially, we adopted a two-step synthetic approach through a thiocarbamate intermediate. Treatment of 2-aminopyridine (1) with S,S-dimethyl dithiocarbonate (DMDTC) under basic conditions led to thiocarbamate $\mathbf{2} .^{12}$ Reaction of $\mathbf{2}$ with the corresponding amines gave pyrid-2-yl ureas 3-6 in moderate yields.

Ureas 9-11 were prepared from the commercially available isocyanate precursors 7 and $\mathbf{8} .{ }^{13}$ To understand the charge effects on the bindings, we have further converted $\mathbf{3}$ and $\mathbf{4}$ to positively charged $\mathbf{1 2}$ and 13,

(12) Leung, M.--k.; Lai, J .-L.; Lau, K.-H.; Yu, H.-h.; Hsiao, H.-J .J J Org. Chem. 1996, 61, 4175.

(13) The compounds were purchased from Acros and were used without further purification.

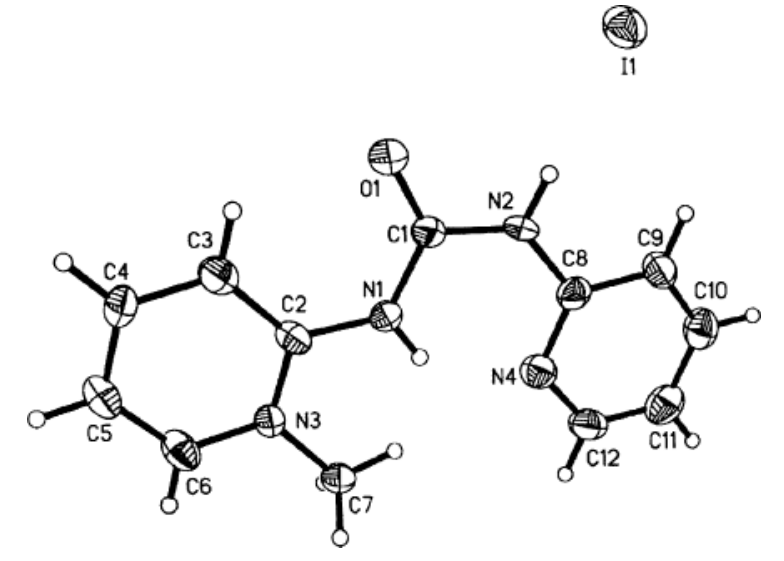

FIGURE 1. ORTEP of $\mathbf{1 2}$.

$\oplus \mathrm{II}$

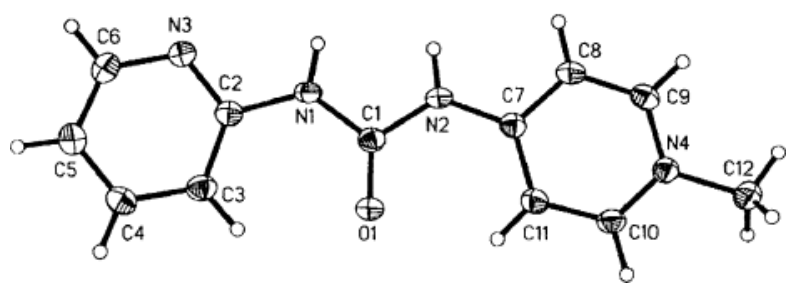

FIGURE 2. ORTEP of $\mathbf{1 3 .}$

respectively, by methylation of the pyridyl substituent with methyl iodide in DMSO. ${ }^{14}$ Interestingly, the reaction stopped at monomethylation to give the desired products. Their structures were further confirmed by X-ray crystallographic analysis.

Single-Crystal X-ray Crystallographic Analyses of $\mathbf{1 2}$ and $\mathbf{1 3}$. Single crystals of $\mathbf{1 2}$ and $\mathbf{1 3}$ were prepared by slow evaporation of the methanol solutions. Crystals of $\mathbf{1 2}$ are triclinic with the space group $\mathrm{P} \overline{1}$ and $Z=4$. Crystals of $\mathbf{1 3}$ are monodinic with the space group $\mathrm{P} 2_{1} / \mathrm{n}$ and $Z=4$. Their ORTEP drawings are shown in Figures 1 and 2 . While $\mathbf{1 3}$ exists in an extended $(Z, Z)$ form in the crystal lattice, $\mathbf{1 2}$ shows an $(E, Z)$ form with $\mathrm{N}(1) \mathrm{H}$ intramol ecul arly hydrogen bonded to the pyridine nitrogen N(4). Both compounds in the crystal lattice are planar with the pyridine rings coplanar with the ureido group.

In compound $\mathbf{1 2}$, the $\mathrm{C}-\mathrm{N}$ bond length for $\mathrm{C}(2)-\mathrm{N}(1)$ was found to be $1.37 \AA$, which is shorter than the $\mathrm{C}-\mathrm{N}$ bond length of $1.39 \AA$ for $C(8)-N(2)$. This result suggested that the contribution of the resonance form of $\mathbf{1 2 b}$

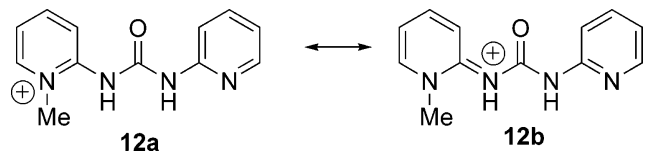

is significant because the ureido nitrogen $N(1)$ tends to donate its lone pair electrons to the electron deficient pyridinium ring. Consistent observation of alternating $\mathrm{C}-\mathrm{C}$ bond lengths on the pyridinium ring further supports this argument. I ndeed, the bond lengths for C(2)-

(14) Mayr, H.; Ofial, A. R.; Sauer, J .; Schmied, B. Eur. J . Org. Chem. 2000, 2013. 
TABLE 1. N-H Chemical Shifts for 3-6 and 9-13 in DMSO- $d_{6}$ at Room Temperature

\begin{tabular}{clcl}
\hline urea & \multicolumn{1}{c}{$\delta(\mathrm{N}-\mathrm{H})$} & urea & \multicolumn{1}{c}{$\delta(\mathrm{N}-\mathrm{H})$} \\
\hline $\mathbf{3}$ & 10.56 & $\mathbf{1 0}$ & $9.34,10.30$ \\
$\mathbf{4}$ & $9.56,10.67$ & $\mathbf{1 1}$ & $8.84,9.08$ \\
$\mathbf{5}$ & $9.62,11.00$ & $\mathbf{1 2}$ & $10.65,(>12)^{\mathrm{a}}$ \\
$\mathbf{6}$ & $9.45,10.62$ & $\mathbf{1 3}$ & $9.97,11.61$ \\
$\mathbf{9}$ & $9.39,10.48$ & &
\end{tabular}

a Estimated on the basis of the broad signal observed at $\delta 14.7$ ppm in DMF $-d_{7}$ at $0{ }^{\circ} \mathrm{C}$.

$C(3)$ and $C(4)-C(5)$ were found to be 1.41 and $1.38 \AA$, respectively, that is, longer than the bond lengths of 1.36 and $1.37 \AA$ for $C(3)-C(4)$ and $C(5)-C(6)$, respectively. While the ureido proton $\mathrm{N}(1) \mathrm{H}$ is hydrogen bonded to $\mathrm{N}(4)$, the second ureido proton on $\mathrm{N}(2)$ is thought to be hydrogen bonded to the iodide anion. The distance between the ureido proton $\mathrm{N}(2) \mathrm{H}$ and $\mathrm{I}^{-}$was estimated to be $2.78 \AA$. This $\mathrm{NH} \cdots \cdot \mathrm{l}$ distance is consistent with the literature values of two-center hydrogen bond lengths to iodide that have been observed in the small molecular crystal structures of nucleic acid components. ${ }^{15}$

Similar situations were observed for $\mathbf{1 3}$. The $\mathrm{C}-\mathrm{N}$ bond length of $1.373 \AA$ for $C(7)-N(2)$ is shorter than that of $1.406 \AA$ for $\mathrm{C}(2)-\mathrm{N}(1)$. Alternating $\mathrm{C}-\mathrm{C}$ bond lengths of the pyridinium ring are even more obvious in this case. The bond lengths of 1.409 and $1.401 \AA$ for $C(7)-C(8)$ and $C(7)-C(11)$, respectively, are longer than the bond lengths of 1.364 and $1.366 \AA$ for $C(8)-C(9)$ and $C(10)-C(11)$, respectively. These observations suggested that the contribution of the resonance form of $\mathbf{1 3 b}$ is important. Both of the ureido protons are thought to be hydrogen bonded with the iodide anion. ${ }^{15}$ However, the distance of $2.694 \AA$ for $\mathrm{N}(2) \mathrm{H} \cdot$. . I is significantly shorter than that of $2.931 \AA$ for $\mathrm{N}(1) \mathrm{H} \cdots \cdot$. .<smiles></smiles>

Thermodynamics of Intramolecular Hydrogen Bonding and Intermolecular Binding with Cytosine. Intramolecular hydrogen bonding interaction was first examined by ${ }^{1} \mathrm{H}$ NMR in DMSO- $\mathrm{d}_{6}$ at room temperature, and the $\mathrm{N}-\mathrm{H}$ resonance signals are summarized in Table 1. While the $\mathrm{N}-\mathrm{H}$ resonance signals of pyrid2-yl substituted ureas 3-6, 9-10, and $\mathbf{1 2 - 1 3}$ are relatively downfield shifted to 9-12 ppm, 11 shows two $\mathrm{N}-\mathrm{H}$ singlets at 8.84 and $9.08 \mathrm{ppm}$. We tentatively attributed the downfield shift phenomenon to being the result of intramolecular hydrogen bonding interactions which favor the formation of the $(E, Z)$ conformers. Since $\mathbf{1 1}$ does not contain a pyrid-2-yl group, we expected that steric repulsion between the phenyl and pyrid-4-yl groups would destabilize the $(E, Z)$ conformer, giving the $(Z, Z)$ conformer as the predominant component. The equilibrium constants $K_{i}$, defined as $[(E, Z)] /[(Z, Z)]$, were further evaluated by ${ }^{1} \mathrm{H} N M R$ in DMF- $\mathrm{d}_{7}$ at a low temperature, and the $\delta$ values are listed in Table $2 .{ }^{11}$ As shown in Figure 3, the conformational exchange between the $\mathrm{E}$ and $\mathbf{Z}$ conformations of $\mathbf{3}$ at room temperature was so fast

(15) J effrey, G. A. An Introduction to Hydrogen Bonding; Oxford: New York, 1997; p 77.
TABLE 2. Chemical Shifts of the Ureido $\mathbf{N}-\mathbf{H}$ Signals of $(E, Z)$ - and $(Z, Z)-3,4,5,9,10,11$, and 12 in DMF-d at - 70 ${ }^{\circ} \mathrm{C}$

\begin{tabular}{rcccr}
\hline urea & $\mathrm{N}_{\mathrm{C}}-\mathrm{H}$ & $\mathrm{N}_{\mathrm{D}}-\mathrm{H}$ & \multicolumn{2}{c}{$\mathrm{N}_{\mathrm{A}}-\mathrm{H}$ and $\mathrm{N}_{\mathrm{B}}-\mathrm{H}$} \\
\hline $\mathbf{3}$ & 12.6 & 10.4 & 9.7 & \\
$\mathbf{4}$ & 12.7 & 10.5 & 9.7 & \\
$\mathbf{5}$ & 13.0 & 10.5 & 10.1 & 9.6 \\
$\mathbf{9}$ & 12.3 & 10.2 & 9.8 & 9.6 \\
$\mathbf{1 0}$ & 12.2 & 10.1 & 9.9 & 9.7 \\
$\mathbf{1 2}$ & 14.7 & 11.2 & 10.6 & 10.5 \\
$\mathbf{1 3}$ & 13.8 & 11.0 & 10.9 & 10.1 \\
\hline
\end{tabular}

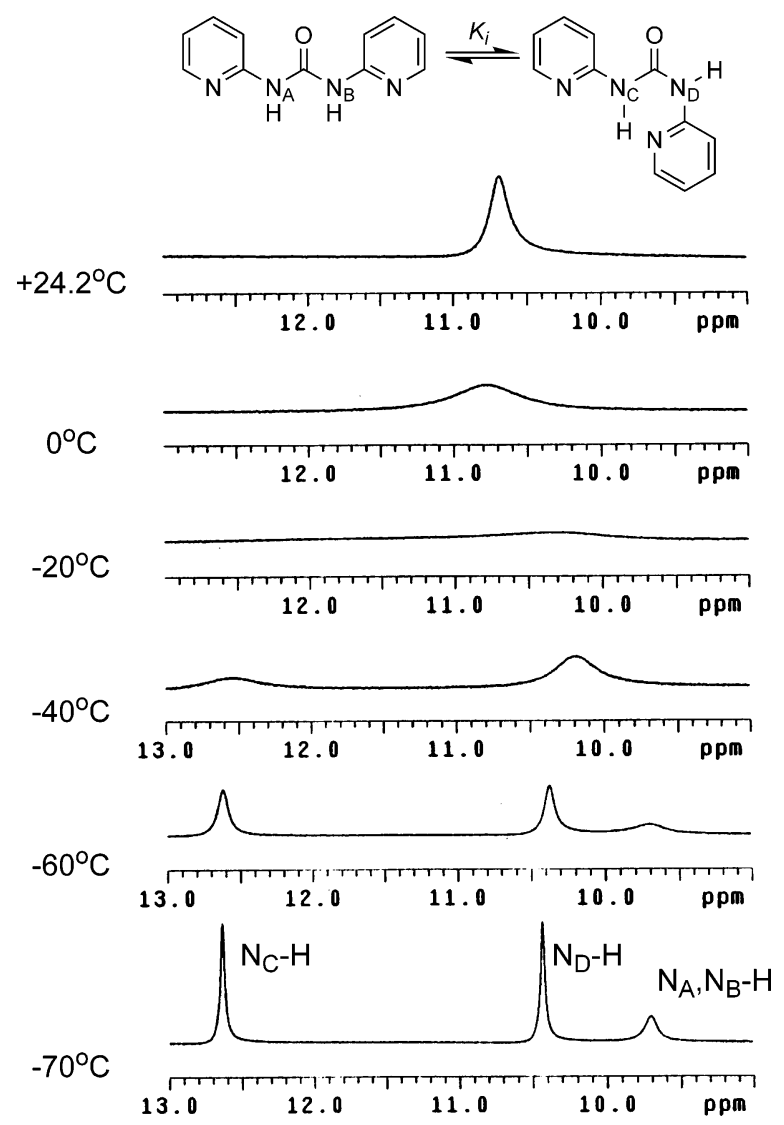

FIGURE 3. ${ }^{1} \mathrm{H}$ NMR spectra of $\mathbf{3}$ at different temperatures.

that only an average $\mathrm{N}-\mathrm{H}$ proton signal was observed. However, the exchange process was significantly slowed at $-70^{\circ} \mathrm{C}$ and two conformers were clearly observed. On the basis of the NMR assignments previously reported in the literature, ${ }^{10 a, b}$ we assigned the signals at $\delta=12.6$ and $10.4 \mathrm{ppm}$ to the urea protons $\mathrm{N}_{\mathrm{C}}-\mathrm{H}$ and $\mathrm{N}_{\mathrm{D}}-\mathrm{H}$ of the $(E, Z)$ conformer, respectively. Since the $\mathrm{N}_{C}-\mathrm{H}$ is intramolecularly hydrogen bonded to the pyridyl group, it is supposed to be relatively downfield shifted. The smaller signal at $9.7 \mathrm{ppm}$ was assigned to the $\mathrm{N}-\mathrm{H}$ protons of the symmetrical $(Z, Z)$ conformer. Perhaps due to a steric hindrance, no evidence for the $(E, E)$ conformer was observed. The equilibrium constant $K_{i}$ was evaluated on the basis of the NMR integrations. To rule out the influence arising from self-association of ureas on the measurement of the equilibrium constants, the concentration-dependence of the $\mathrm{NH}$ chemical shifts was examined. Indeed, identical NM R spectra were obtained in the concentration range $0.008-0.014 \mathrm{M}$. These results imply that self-association of urea in this concentration range is less important. Similar assignments have been made 
TABLE 3. Equilibrium Constants and Thermodynamic Parameters for the Pyrid-2-yl Ureas

\begin{tabular}{rlcrr}
\hline urea & \multicolumn{1}{c}{$\mathrm{K}_{\mathrm{i}}{ }^{\mathrm{a}}$} & $\Delta \mathrm{H}_{\mathrm{i}}{ }^{\circ \mathrm{c}}$ & $\Delta \mathrm{S}_{\mathrm{i}}{ }^{\circ \mathrm{d}}$ & $\mathrm{K}_{\mathrm{B}}\left(\mathrm{M}^{-1}\right)$ \\
\hline $\mathbf{3}$ & $3.8(1.9)^{\mathrm{b}}$ & -2.3 & -8.8 & 30 \\
$\mathbf{4}$ & 1.7 & & & 590 \\
$\mathbf{5}$ & 2.0 & & & 1100 \\
$\mathbf{9}$ & 1.6 & & & 390 \\
$\mathbf{1 0}$ & 2.0 & & & 340 \\
$\mathbf{1 2}$ & 14.2 & -0.8 & 1.3 & $\mathrm{e}$ \\
$\mathbf{1 3}$ & 1.0 & -2.2 & -10.6 & 1700
\end{tabular}

${ }^{a} K_{i}=[(E, Z)] /[(Z, Z)] .{ }^{b}$ Due to the symmetry of $\mathbf{3}$, formation of intramolecular hydrogen interaction is 2 times greater than that of the others. ${ }^{c} \mathrm{kcal} / \mathrm{mol}$, estimated relative error $<20 \%{ }^{d} \mathrm{cal} /$ $\mathrm{mol} \cdot \mathrm{K}$. e Unknown product was observed.

for 4-6, 9, 10, 12, and $\mathbf{1 3}$ (Table 2). Perhaps due to the relatively low rotational energy barrier that leads to a faster $\mathrm{N}-\mathrm{C}=\mathrm{O}$ bond rotation, the $\mathrm{N}-\mathrm{H}$ proton signals of 4-6, 9, and 10 were broad in comparison to those of 3, 12, and 13. Except for the case of $\mathbf{6}$, nevertheless, their equilibrium constants could be reasonably estimated and are summarized in Table 3. Among the pyrid-2-yl ureas we studied, most of them have a $K_{i}$ value of around 1-2, indicating that there is only a small preference for the $(E, Z)$ form over the $(Z, Z)$ form.

However, the $K_{i}$ value of $14.2 \pm 1.2$ for 12 is unusually high and is almost 1 order of magnitude larger than the others. The results of the temperature-dependent experiments revealed that the preference for the intramolecular hydrogen bonding interaction arises from the entropy factors. The $(E, Z)$ conformation of $\mathbf{1 2}$ is indeed less exothermic but entropically favored in comparison to the cases of $\mathbf{3}$ and $\mathbf{1 3}$. The positive change in entropy for intramolecular folding of $\mathbf{1 2}$ to give the $(E, Z)$ conformer is in sharp contrast to those of $\mathbf{3}$ and $\mathbf{1 3}$. Since there is a positively charged methylpyridinium-2-yl group on $\mathbf{1 2}$, solvation of this group by polar aprotic DMF molecules should be significantly strong. Since this methylpyridinium-2-yl center is adjacent to the ureido $\mathrm{N}_{C}-\mathrm{H}$ group, intramolecular folding of $\mathbf{1 2}$ from the $(Z, Z)$ form to the $(E, Z)$ form would partially occupy the solvation shell, leading to a loss of the solvation enthalpy. This could explain the observation of a less negative $\Delta \mathrm{H}^{\circ}$ value for 12. Moreover, releasing solvent molecules from the solvation shell during intramolecular hydrogen bond formation would lead to an increase of reaction entropy. This kind of enthal py-entropy compensation relationship has been discussed in recent literature. ${ }^{16}$

Intermolecular complexation of pyridyl ureas with cytosine has also been studied by ${ }^{1} \mathrm{H}$ NMR at $-70{ }^{\circ} \mathrm{C}$. A similar equilibrium system of model receptors for adenine derivatives had been reported by Rebek. ${ }^{17}$ I $\mathrm{n}$ each series of studies, the concentration of cytosine was gradually increased while the concentration of the target pyridyl ureas was kept constant at around $0.01 \mathrm{M}$. Example spectra of $\mathbf{1 3}$ are shown in Figure 4. Upon increasing the amount of cytosine, the $\mathrm{N}-\mathrm{H}$ chemical shifts $\delta_{\mathrm{Z}, \mathrm{Z}}$ of $(\mathrm{Z}, \mathrm{Z})$ $\mathbf{1 3}$ gradually shifted from 10.1 and 10.9 ppm to 12.1 and 13.1 ppm, respectively, indicating complex formation

(16) (a) Williams, D. H.; O'Brien, D. P.; Bardsley, B. J . Am. Chem. Soc. 2001, 123, 737. (b) Leung, M.-k.; Mandal, A. B.; Wang, C.-C.; Lee G.-H.; Peng, S. M.; Cheng, H.-L.; Her, G.-R.; Chao, I.; Lu, H.-F .; Sun, Y.-C.; Shiao, M.-Y.; Chou, P. T. J . Am. Chem. Soc. 2002, 124, 4287.

(17) Tjivikua, T.; Deslongchamps, G.; Rebek, J ., J r. J . Am. Chem. Soc. 1990, 112, 8408.

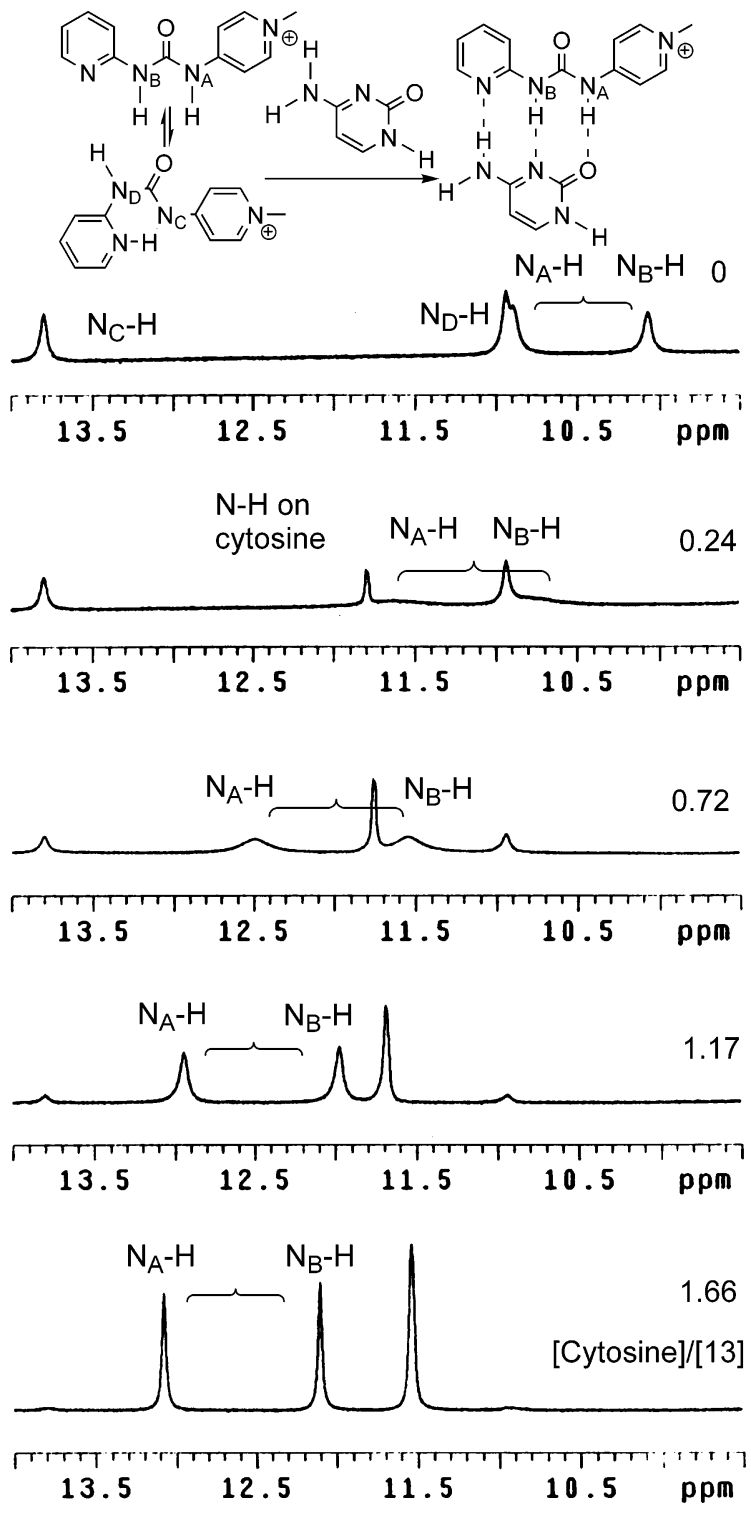

FIGURE 4. ${ }^{1} \mathrm{H}$ NMR spectra of $\mathbf{1 3}$ in the presence of different equivalents of cytosine at $-70^{\circ} \mathrm{C}$ in DMF- $\mathrm{d}_{7}$.

between cytosine and 13. Although the assignments for $\mathrm{N}_{\mathrm{A}}-\mathrm{H}$ and $\mathrm{N}_{\mathrm{B}}-\mathrm{H}$ are not immediately obvious, the binding constants $K_{B}$ could still be unambiguously evaluated on the basis of the trend of the $\mathrm{N}-\mathrm{H}$ signal shifts. On the other hand, the $\mathrm{N}-\mathrm{H}$ signal intensities of the $(E, Z)$ isomer at 13.8 and 10.9 ppm progressively dropped without any shift of the $\delta$ values. These observations are consistent with our assumption that only $(Z, Z)-\mathbf{1 3}$ would bind with cytosine. However, binding between cytosine and $(Z, Z)-13$ would shift the equilibrium toward the $(Z, Z)-13$ side, reducing the amounts of $(E, Z)-13$ in solution.

As shown in Figure 5, the tendency of the $\delta_{z, z}$ values follows the mathematical expression $\delta_{z, Z}=\left(\delta_{i}+\delta_{f} K_{B}[C]\right) /$ $\left(1+K_{B}[C]\right)$, where $[C]$ is the concentration of free cytosine in solution, $\delta_{\mathrm{i}}$ is the initial chemical shift before addition of cytosine, and $\delta_{f}$ is the final chemical shift in the presence of a large excess of cytosine. The binding constants $K_{B}$ were evaluated on the basis of a nonlinear least-squares fitting of $\delta_{z, z}$ versus the concentration of free cytosine, and they are summarized in Table 3. 


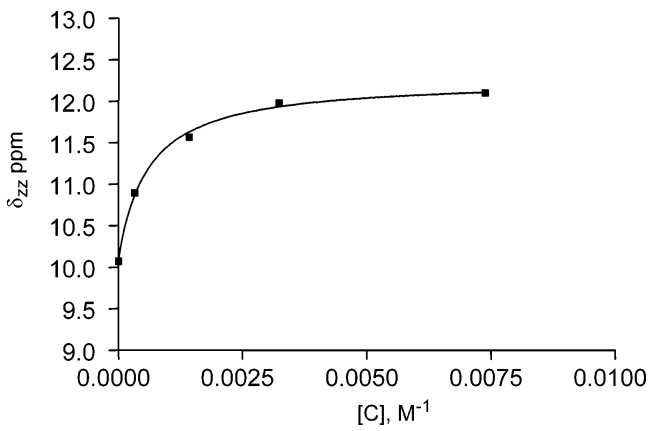

FIGURE 5. Plot of the $\mathrm{N}-\mathrm{H}$ chemical shifts $\delta_{\mathrm{Z}, \mathrm{Z}}$ of $(\mathrm{Z}, \mathrm{Z})-\mathbf{1 3}$ vs $[C]$, the concentration of free cytosine in solution.

Pyrid-2-yl ureas containing electron deficient or electron withdrawing groups, such as $\mathbf{5}$ or $\mathbf{1 3}$, show relatively large binding constants $K_{B}$ of 1100 and $1700 \mathrm{M}^{-1}$, respectively. In particular, $\mathbf{1 3}$ is the strongest receptor for cytosine in the studied series, indicating the significance of the charge effects on the binding. Wetentatively correlate this observation to the field-effect acidity enhancement of the $\mathrm{N}_{\mathrm{A}}-\mathrm{H}$ by the attached electron withdrawing aryl substituent and the partial positive-charge delocalization onto the $\mathrm{N}_{\mathrm{A}}$ atom described in the discussion of the X-ray crystallography. Although the acidbase properties are far from linearly correlated to the strengths of the hydrogen bonds, there are obvious relationships between them. ${ }^{17}$ As the data in Table 2 show, the $\delta$ values of 10.1 and $10.9 \mathrm{ppm}$ were found for the $N_{A}-H$ protons of $(Z, Z)-5$ and $(Z, Z)-13$, respectively, which are relatively more downfield than the average $\delta$ value of $9.7 \pm 0.1 \mathrm{ppm}$ for the other ureido protons. These imply that the $\mathrm{N}_{\mathrm{A}}-\mathrm{H}$ group is a stronger hydrogen bond donor than the normal ureido protons. According to these results, we proposed that the $\mathrm{N}_{\mathrm{A}}-\mathrm{H}$ of $(\mathrm{Z}, \mathrm{Z})-5$ and $(\mathrm{Z}, \mathrm{Z})$ $\mathbf{1 3}$ would be relatively acidic and therefore favorable for hydrogen bonding with cytosine. ${ }^{18}$ Furthermore, the partial positive charge delocalized onto the $\mathrm{N}_{\mathrm{A}}$ atom through resonance from the attached pyridinium substituent of $\mathbf{1 3}$ would attract the partial negative charge on the $\mathrm{C}=\mathrm{O}$ group of cytosine, which is beneficial for the hydrogen bond complex formation. Although we expected that $\mathbf{1 2}$ would also be a strong cytosine binder, the binding constant measurement of $\mathbf{1 2}$ with cytosine was unfortunately hampered by formation of an unidentified compound and could not be evaluated.

The $K_{B}$ value of $30 \mathrm{M}^{-1}$ for $\mathbf{3}$ is particularly small in comparison to the others in the series. We tentatively attribute this phenomenon to the secondary el ectrostatic repulsion between the pyridyl nitrogen and the carbonyl group of cytosine in 14. The secondary electrostatic repulsion model was proposed by J orgenson and later on quantified by Schneider. ${ }^{19}$ Although one may suggest that rotation of the pyridyl group away from the cytosine would lead to less repulsion, as shown in 15, this will create another el ectrostatic repulsion between the pyridyl nitrogen and the ureyleno carbonyl group.

In summary, we report herein the unexpected substituent effects on aryl pyrid-2-yl ureas toward intramo-

(18) For reviews of the relationship between hydrogen bond strength and acid-base properties, see: (a) Pogorelyi, V. K.; Vishnyakova, T. B. Russ. Chem. Rev. 1984, 53, 1154. (b) Epshtein, L. M. Russ. Chem. Rev. 1979, 48, 854 .
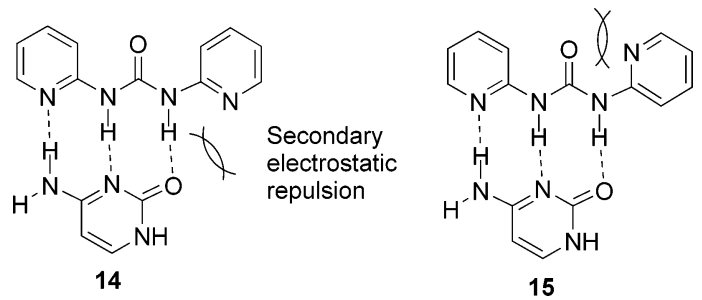

lecular hydrogen bonding and cytosine complexation. The $\mathrm{N}$-methylpyridinium derivative $\mathbf{1 2}$ shows an unexpectedly strong tendency toward intramolecular hydrogen bond interactions. On the other hand, the introduction of an electron withdrawing substituent at the para position of aryl pyrid-2-yl ureas particularly enhances the intermolecular cytosine binding. Application of this concept to the design of DNA binders is ongoing.

\section{Experimental Section}

${ }^{1} H$ NMR Experiments for the Determination of $K_{i}$ and $\mathbf{K}_{\mathbf{B}}$. The ${ }^{1} \mathrm{H}$ NMR experiments were carried out in predried $D M F-d_{7}$ at low temperature. DMF $-d_{7}$ was predried from molecular sieves $4 \mathrm{~A}$ and distilled. Equilibrium constants $\mathrm{K}_{i}$ were measured at $-70^{\circ} \mathrm{C}$ on the basis of the NMR integration of each isomer. To obtain the thermodynamic parameters $\Delta \mathrm{H}_{\mathrm{i}}{ }^{\circ}$ and $\Delta S_{i}{ }^{\circ}$ for $\mathbf{3}, \mathbf{1 2}$, and $\mathbf{1 3}$, temperature-dependent experiments were carried out respectively at 203.25, 213.22, and $233.10 \mathrm{~K}$. The concentration of the samples was set at 0.01 $M$. On the basis of the equation $\Delta \mathrm{G}_{\mathrm{i}}{ }^{\circ}=-\mathrm{RT}$ In $\mathrm{K}_{\mathrm{i}}=\Delta \mathrm{H}_{\mathrm{i}}{ }^{\circ}-$ $\mathrm{T} \Delta \mathrm{S}_{i}^{\circ}$, the values of $\Delta \mathrm{H}_{\mathrm{i}}^{\circ}$ and $\Delta \mathrm{S}^{\circ}{ }^{\circ}$ for $\mathbf{3}, \mathbf{1 2}$, and 13 were evaluated from the linear regression of In $\mathrm{K}_{\mathrm{i}}$ versus $1 / \mathrm{T}$.

To determine the cytosine binding constants $\mathrm{K}_{\mathrm{B}},{ }^{1} \mathrm{H} N M R$ titration experiments were carried out at $-70{ }^{\circ} \mathrm{C}$ in DMF- $\mathrm{d}_{7}$. The concentration of cytosine was increased gradually, while the concentration of urea was kept constant. The binding constants were evaluated on the basis of the nonlinear regression method shown in the Supporting I nformation. The binding constants were doubly checked by the integration approach. The data were also shown in the Supporting I nformation. The values from the two approaches are consistent with each other.

S-Methyl (N-(Pyrid-2-yl)thiocarbamate (2). ${ }^{20}$ To a solution of 2-aminopyridine $(4.11 \mathrm{~g}, 43.7 \mathrm{mmol})$ and 1,1,1,3,3,3hexamethyldisilazane $(7.24 \mathrm{~g}, 44.9 \mathrm{mmol})$ in THF $(35 \mathrm{~mL})$ under $\mathrm{N}_{2}$ at $-78{ }^{\circ} \mathrm{C}$ was added n-butyllithium (1.6 $\mathrm{M}$ in hexane, $87.2 \mathrm{mmol}$ ). After addition, the solution was stirred for $30 \mathrm{~min}$, and a solution of DMDTC $(5.45 \mathrm{~g}, 44.6 \mathrm{mmol})$ in THF $(10 \mathrm{~mL})$ was added. The reaction mixture was further stirred for $20 \mathrm{~h}$, and during the course of this, the temperature was gradually raised to room temperature. The reaction was quenched by addition of water. The product was collected by extraction with $\mathrm{CH}_{2} \mathrm{Cl}_{2}$ for three times. The organic extracts were collected, dried over anhydrous $\mathrm{MgSO}_{4}$, concentrated, and recrystallized from hexane- $\mathrm{CH}_{2} \mathrm{Cl}_{2}$ to give col orless crystals (5.51 g, $32.8 \mathrm{mmol}, 47 \%$ ). mp $116-118{ }^{\circ} \mathrm{C}$ (lit. ${ }^{17} 113-114$, EtOH); ${ }^{1} \mathrm{H} \mathrm{NMR}\left(400 \mathrm{MHz}, \mathrm{DMSO}-\mathrm{d}_{6}\right) \delta 10.90(\mathrm{~s}, 1 \mathrm{H}), 8.27$ $(\mathrm{m}, 1 \mathrm{H}), 7.83(\mathrm{~d}, \mathrm{~J}=8 \mathrm{~Hz}, 1 \mathrm{H}), 7.76(\mathrm{~m}, 1 \mathrm{H}), 7.07(\mathrm{~m}, 1 \mathrm{H})$, $2.27(\mathrm{~s}, 3 \mathrm{H}) ;{ }^{13} \mathrm{C} N M R\left(75 \mathrm{MHz} \mathrm{CDCl}_{3}\right) \delta 167.0,151.8,147.8$, 138.7, 119.2, 114.1, 12.3; IR (KBr) $\left(\mathrm{cm}^{-1}\right) 3448(\mathrm{NH}), 1695(\mathrm{C}=$ O); MS (El, $70 \mathrm{eV}) \mathrm{m} / \mathrm{e} 168\left(\mathrm{M}^{+}, 15\right), 153(65), 121$ (53), 78 (100); HRMS (EI, $70 \mathrm{eV}$ ) calcd for $\mathrm{C}_{7} \mathrm{H}_{8} \mathrm{~N}_{2} \mathrm{OS}$ 168.0357, obsd 168.0363. Anal. Calcd for $\mathrm{C}_{7} \mathrm{H}_{8} \mathrm{~N}_{2} \mathrm{OS}$ : C, 49.98; $\mathrm{H}, 4.79 ; \mathrm{N}$, 16.65. Found: $\mathrm{C}, 49.82 ; \mathrm{H}, 4.73 ; \mathrm{N}, 16.68$.

(19) (a) Pranata, I : Wierschke, S. G : J orgensen, W. L. J Am. Chem Soc. 1991, 113, 2810. (b) J orgensen, W. L.; Pranata, J . J . Am. Chem. Soc. 1990, 112, 2008. (c) Sartorius, J .; Schneider, H.-J . Chem.-Eur . 1996, 2, 1446

(20) Gilbert, G.; Wetstein, H. U.S. Patent 3284460, 1966; Chem Abstr. 1968, 49462 .

1870 J. Org. Chem., Vol. 69, No. 6, 2004 
$\mathbf{N}, \mathbf{N}^{\prime}$-Di(pyrid-2-yl)urea (3). ${ }^{10 \mathrm{~b}} \mathrm{~A}$ solution of 2-aminopyridine $(3.60 \mathrm{~g}, 38.6 \mathrm{mmol})$ and $2(5.00 \mathrm{~g}, 29.7 \mathrm{mmol})$ in THF (12 mL) was refluxed for $24 \mathrm{~h}$. The solvent was then removed under reduced pressure by using a rotary evaporator. The crude solid was then recrystallized from $\mathrm{CHCl}_{3}$ to give 3 as colorless crystals $(4.00 \mathrm{~g}, 8.7 \mathrm{mmol}, 62 \%) . \mathrm{mp} 174-176{ }^{\circ} \mathrm{C} ;{ }^{1} \mathrm{H}$ NMR (400 MHz, DMSO-d 6 ) $\delta 10.56$ (bs, 2H), 8.27-8.29 (m, $2 \mathrm{H}), 7.72-7.76(\mathrm{~m}, 2 \mathrm{H}), 7.65-7.71(\mathrm{~m}, 2 \mathrm{H}), 7.02-7.05(\mathrm{~m}, 2 \mathrm{H})$; ${ }^{13} \mathrm{C}$ NMR $\left(400 \mathrm{MHz}, \mathrm{DMSO}-\mathrm{d}_{6}\right) \delta 152.4,151.9,147.3,138.5$, 118.2, 112.4; IR (KBr) $\left(\mathrm{cm}^{-1}\right) 3226(\mathrm{NH}), 1701(\mathrm{C}=\mathrm{O}) ; \mathrm{FAB}$ (NBA) $215.1\left(\mathrm{M}^{+}+\mathrm{H}\right)$; HRMS (FAB) calcd for $\mathrm{C}_{11} \mathrm{H}_{10} \mathrm{~N}_{4} \mathrm{O}$ $214.0855\left(\mathrm{M}^{+}+\mathrm{H}\right)$, obsd 214.0978 .

$\mathbf{N}$-(Pyrid-4-yl)-N'-(pyrid-2-yl)urea (4). ${ }^{10 b}$ A solution of 4-aminopyridine $(0.73 \mathrm{~g}, 7.8 \mathrm{mmol})$ and 2 ( $1.00 \mathrm{~g}, 5.90 \mathrm{mmol})$ in THF $(2.7 \mathrm{~mL})$ was refluxed for $19 \mathrm{~h}$. The solvent was removed under reduced pressure by using a rotary evaporator. The crude solid collected was then recrystallized from methanol to give 4 as col orless crystals $(0.18 \mathrm{~g}, 0.8 \mathrm{mmol}, 14 \%)$. $\mathrm{mp} 192-194{ }^{\circ} \mathrm{C}$; ${ }^{1} \mathrm{H}$ NMR $\left(400 \mathrm{MHz}, \mathrm{DMSO}_{-} \mathrm{d}_{6}\right) \delta 10.68$ (bs, $1 \mathrm{H}), 9.56(\mathrm{~s}, 1 \mathrm{H}), 8.38(\mathrm{~d}, \mathrm{~J}=5 \mathrm{~Hz}, 2 \mathrm{H}), 8.28-8.29(\mathrm{~m}, 1 \mathrm{H})$, 7.76-7.78 (m, $1 \mathrm{H}), 7.55(\mathrm{~d}, \mathrm{~J}=8 \mathrm{~Hz}, 1 \mathrm{H}), 7.50(\mathrm{~d}, \mathrm{~J}=5 \mathrm{~Hz}$, $2 \mathrm{H}), 7.03-7.05(\mathrm{~m}, 1 \mathrm{H}) ;{ }^{13} \mathrm{C}$ NMR $\left(400 \mathrm{MHz}, \mathrm{DMSO}-\mathrm{d}_{6}\right) \delta$ 152.3, 151.9, 150.3, 147.1, 145.8, 138.7, 118.1, 112.8, 112.1; IR (KBr) $\left(\mathrm{cm}^{-1}\right) 3230(\mathrm{NH}), 1704(\mathrm{C}=\mathrm{O}) ; \mathrm{FAB}(\mathrm{NBA}) 215.1\left(\mathrm{M}^{+}\right.$ $+\mathrm{H})$; HRMS (FAB) calcd for $\mathrm{C}_{11} \mathrm{H}_{11} \mathrm{~N}_{4} \mathrm{O} 215.0933\left(\mathrm{M}^{+}+\mathrm{H}\right)$, obsd 215.0930.

N-(4-Nitrophenyl)-N' $\mathbf{N}^{\prime}$ (pyrid-2-yl)urea (5). ${ }^{8 d}$ A solution of 4-nitroaniline (1.07 g, $7.7 \mathrm{mmol})$ and 2 (1.01 g, $6.0 \mathrm{mmol}$ ) in THF $(2.6 \mathrm{~mL})$ was refluxed for $24 \mathrm{~h}$. Rotary evaporation of the solvent gave a crude solid that was further recrystallized from EtOAc to give 5 as a slightly brownish solid $(0.59 \mathrm{~g}, 2.3$ $\mathrm{mmol}, 38 \%) . \mathrm{mp} 246-248{ }^{\circ} \mathrm{C} ;{ }^{1} \mathrm{H}$ NMR (400 MHz, DMSO-d $\left.\mathrm{d}_{6}\right)$ $\delta 11.01(\mathrm{bs}, 1 \mathrm{H}), 9.62(\mathrm{bs}, 1 \mathrm{H}), 8.28-8.30(\mathrm{~m}, 1 \mathrm{H}), 8.19(\mathrm{~d}, \mathrm{~J}=$ $8 \mathrm{~Hz}, 2 \mathrm{H}), 7.74-7.78(\mathrm{~m}, 3 \mathrm{H}), 7.52(\mathrm{~d}, \mathrm{~J}=8 \mathrm{~Hz}, 1 \mathrm{H}), 7.02-$ $7.05(\mathrm{~m}, 1 \mathrm{H}) ;{ }^{13} \mathrm{C}$ NMR $(400 \mathrm{MHz}$, DMSO-d 6$) \delta 152.8,152.3$, $147.5,146.0,142.0,139.2,125.6,118.7,118.6,112.6$; IR (KBr) $\left(\mathrm{cm}^{-1}\right) 3218(\mathrm{NH}), 1705(\mathrm{C}=\mathrm{O}) ; \mathrm{FAB}(\mathrm{NBA}) 259.1\left(\mathrm{M}^{+}+\mathrm{H}\right)$; HRMS (FAB) calcd for $\mathrm{C}_{12} \mathrm{H}_{11} \mathrm{~N}_{4} \mathrm{O}_{3} 259.0831\left(\mathrm{M}^{+}+\mathrm{H}\right)$, obsd 259.0837.

N-(4-Chlorophenyl)-N'-(pyrid-2-yl)urea (6). ${ }^{21} \mathrm{~A}$ solution of 4-chloroaniline $(0.98 \mathrm{~g}, 7.7 \mathrm{mmol})$ and 2 (1.01 g, $6.0 \mathrm{mmol}$ ) in THF $(2.6 \mathrm{~mL})$ was refluxed for $36 \mathrm{~h}$. Rotary evaporation of the solvent gave a crude solid that was further recrystallized from EtOAc to give 6 as colorless needles $(0.70 \mathrm{~g}, 2.8 \mathrm{mmol}$, 47\%). mp 205-207 ${ }^{\circ} \mathrm{C}$; ${ }^{1} \mathrm{H}$ NMR (400 MHz, DMSO-d 6 ) $\delta 10.62$ $(\mathrm{s}, 1 \mathrm{H}), 9.45(\mathrm{~s}, 1 \mathrm{H}), 8.25-8.27(\mathrm{~m}, 1 \mathrm{H}), 7.73-7.77(\mathrm{~m}, 1 \mathrm{H})$, $7.55(\mathrm{~d}, \mathrm{~J}=8 \mathrm{~Hz}, 2 \mathrm{H}), 7.46(\mathrm{~d}, \mathrm{~J}=8 \mathrm{~Hz}, 1 \mathrm{H}), 7.34(\mathrm{~d}, \mathrm{~J}=8$ $\mathrm{Hz}, 2 \mathrm{H}), 6.98-7.02(\mathrm{~m}, 1 \mathrm{H}) ;{ }^{13} \mathrm{C}$ NMR $\left(400 \mathrm{MHz}, \mathrm{DMSO}_{6} \mathrm{~d}_{6}\right) \delta$ 153.2, 152.6, 147.4, 139.1, 138.5, 129.2, 126.5, 120.8, 118.1, 112.4; IR (KBr) $\left(\mathrm{cm}^{-1}\right) 3219(\mathrm{NH}), 1696(\mathrm{C}=\mathrm{O}) ; \mathrm{FAB}(\mathrm{NBA})$ $248.0\left(M^{+}+\mathrm{H}\right)$; HRMS (FAB) calcd for $\mathrm{C}_{12} \mathrm{H}_{11} \mathrm{CIN}_{3} \mathrm{O} 248.0591$ $\left(\mathrm{M}^{+}+\mathrm{H}\right)$, obsd 248.0599 .

1-Methyl-2-(3-(pyrid-2-yl)ureido)pyridinium Iodide (12). To a solution of $\mathbf{3}(0.50 \mathrm{~g}, 2.3 \mathrm{mmol})$ in DMSO $(2.6 \mathrm{~mL})$ was added $\mathrm{Mel}(0.44 \mathrm{~mL}, 0.99 \mathrm{~g}, 7.0 \mathrm{mmol})$. After the mixture was stirred for $2 \mathrm{~h}$, a yellowish precipitate formed. The reaction was monitored by ${ }^{1} \mathrm{H}$ NMR and finished after $7 \mathrm{~h}$. The product was precipitated by addition of ethyl acetate, collected by suction filtration, washed with distilled water, and dried under vacuum to give $12(0.35 \mathrm{~g}, 1.0 \mathrm{mmol}, 42 \%)$ as colorless crystals. mp 187-190 ${ }^{\circ} \mathrm{C} ;{ }^{1} \mathrm{H}$ NMR (400 MHz, DMSO-d 6 ) $\delta 10.66$ (bs, $1 \mathrm{H}), 8.73(\mathrm{~d}, \mathrm{~J}=6 \mathrm{~Hz}, 1 \mathrm{H}), 8.65(\mathrm{~d}, \mathrm{~J}=8 \mathrm{~Hz}, 1 \mathrm{H}), 8.41-8.43$ $(\mathrm{m}, 1 \mathrm{H}), 8.37(\mathrm{t}, \mathrm{J}=8 \mathrm{~Hz}, 1 \mathrm{H}), 7.88-7.92(\mathrm{~m}, 1 \mathrm{H}), 7.52-7.58$ (bt, $1 \mathrm{H}), 7.27-7.33(\mathrm{bs}, 1 \mathrm{H}), 7.16-7.18(\mathrm{~m}, 1 \mathrm{H}), 4.22(\mathrm{~s}, 3 \mathrm{H})$; ${ }^{13} \mathrm{C}$ NMR $\left(400 \mathrm{MHz}, \mathrm{DMSO}-\mathrm{d}_{6}\right) \delta 151.6,151.0,149.3,145.9$, 144.8, 143.6, 140.2, 119.0, 118.5, 117.9, 112.1, 43.9; IR (KBr) $\left(\mathrm{cm}^{-1}\right) 3145(\mathrm{NH}), 1734(\mathrm{C}=\mathrm{O}) ; \mathrm{FAB}(\mathrm{NBA}) 229.1\left(\mathrm{M}^{+}\right)$; HRMS (FAB) calcd for $\mathrm{C}_{12} \mathrm{H}_{13} \mathrm{~N}_{4} \mathrm{O}^{+} 229.1089\left(\mathrm{M}^{+}\right)$, obsd 229.1090 .

1-Methyl-4-(3-(pyrid-2-yl)ureido)pyridinium Iodide (13). To a solution of $4(0.8 \mathrm{~g}, 4 \mathrm{mmol})$ in DMSO $(4 \mathrm{~mL})$ at $30{ }^{\circ} \mathrm{C}$

(21) Le Magueres, P.; Ouahab, L.; Hocquet, A.; Fournier, J . Acta Crystallogr. 1994, C50, 1507. was added Mel $\left(0.7 \mathrm{~mL}\left(\mathrm{CH}_{3} \mathrm{l}\right), 1.6 \mathrm{~g}, 11 \mathrm{mmol}\right)$. After the mixture was stirred for $2 \mathrm{~h}$, a yellowish precipitate formed. The reaction was monitored by ${ }^{1} \mathrm{H}$ NMR and finished after 11 h. The product was precipitated by addition of ethyl acetate, collected by suction filtration, washed with distilled water, and dried under vacuum to give $\mathbf{1 3}(0.4 \mathrm{~g}, 1 \mathrm{mmol}, 33 \%)$ as slightly yellowish crystals. mp $218-220{ }^{\circ} \mathrm{C}$; ${ }^{1} \mathrm{H}$ NMR $(400 \mathrm{MHz}$, DMSO- $\left._{6}\right) \delta 11.61(\mathrm{~s}, 1 \mathrm{H}), 9.98(\mathrm{~s}, 1 \mathrm{H}), 8.66(\mathrm{~d}, \mathrm{~J}=8 \mathrm{~Hz}, 2 \mathrm{H})$, $8.33-8.35(\mathrm{~m}, 1 \mathrm{H}), 8.04(\mathrm{~d}, \mathrm{~J}=8 \mathrm{~Hz}, 2 \mathrm{H}), 7.82-7.85(\mathrm{~m}, 1 \mathrm{H})$, $7.59(\mathrm{~d}, \mathrm{~J}=8 \mathrm{~Hz}, 1 \mathrm{H}), 7.11-7.16(\mathrm{~m}, 1 \mathrm{H}), 4.14(\mathrm{~s}, 3 \mathrm{H}) ;{ }^{13} \mathrm{C}$ NMR $\left(400 \mathrm{MHz}, \mathrm{DMSO}-\mathrm{d}_{6}\right) \delta 151.9,151.5,151.3,147.4,145.6$, 139.1, 119.0, 114.2, 112.5, 46.1; IR $(\mathrm{KBr})\left(\mathrm{cm}^{-1}\right) 3238(\mathrm{NH})$, $1729(\mathrm{C}=\mathrm{O})$; FAB (NBA) $229.1\left(\mathrm{M}^{+}\right)$; HRMS (FAB) calcd for $\mathrm{C}_{12} \mathrm{H}_{13} \mathrm{~N}_{4} \mathrm{O}^{+} 229.1089\left(\mathrm{M}^{+}\right)$, obsd 229.1087.

N-Phenyl-N'-(pyrid-2-yl)urea (9). ${ }^{1 \text { of }}$ To a solution of 2-aminopyridine (0.95 g, $10.1 \mathrm{mmol}$ ) in $\mathrm{CaH}_{2}$ dried 1,4-dioxane under nitrogen was added phenylisocyanate $(1.5 \mathrm{~mL}, 13.7 \mathrm{mmol})$. After being refluxed for $1 \mathrm{~h}$, the solution was cooled to room temperature and white preci pitate formed. The precipitate was collected by suction filtration and recrystallized from EtOH to give 9 as white solid (0.85 g, $4.0 \mathrm{mmol}, 39 \%) . \mathrm{mp} 201-204$ ${ }^{\circ} \mathrm{C}$; ${ }^{1} \mathrm{H}$ NMR $\left(400 \mathrm{MHz}, \mathrm{DMSO}-\mathrm{d}_{6}\right) \delta 10.48(\mathrm{~s}, 1 \mathrm{H}), 9.40(\mathrm{~s}, 1 \mathrm{H})$, 8.25-8.27 (m, $1 \mathrm{H}), 7.770-7.76(\mathrm{~m}, 1 \mathrm{H}), 7.47-7.52(\mathrm{~m}, 3 \mathrm{H})$, $7.28-7.32(\mathrm{~m}, 2 \mathrm{H}), 6.97-7.03(\mathrm{~m}, 2 \mathrm{H}) ;{ }^{13} \mathrm{C} \mathrm{NMR}(400 \mathrm{MHz}$ DMSO-d $\left.\mathrm{d}_{6}\right) \delta 152.9,152.2,146.9,139.0,138.5,128.9,122.5$, 118.8, 117.5, 111.9; IR (KBr) $\left(\mathrm{cm}^{-1}\right) 3224(\mathrm{NH}), 1691(\mathrm{C}=\mathrm{O})$; FAB (NBA) $214.1\left(\mathrm{M}^{+}+\mathrm{H}\right)$; HRMS (FAB) calcd for $\mathrm{C}_{12} \mathrm{H}_{11} \mathrm{~N}_{3} \mathrm{O}$ $214.0980\left(\mathrm{M}^{+}+\mathrm{H}\right)$, obsd 214.0983 .

N-(4-Methoxyphenyl)-N'-(pyrid-2-yl)urea (10).22 To a solution of 2-aminopyridine $(0.60 \mathrm{~g}, 6.4 \mathrm{mmol})$ in THF (14 mL) was added 4-methoxyphenylisocyanate $(1.01 \mathrm{~mL}, 7.7 \mathrm{mmol})$. After being refluxed for $1 \mathrm{~h}$, the solution was cooled to room temperature. The white precipitate formed was collected by suction filtration. Recrystallization of the precipitate from EtOH -EtOAc gave 10 as col or less needles (1.24 g, $5.1 \mathrm{mmol}$, 80\%). mp 213-215 ${ }^{\circ} \mathrm{C}$ (lit. ${ }^{19}$ 206-207); ${ }^{1} \mathrm{H}$ NMR (400 MHz, DMSO-d $\left.\mathrm{d}_{6}\right) \delta 10.37(\mathrm{~s}, 1 \mathrm{H}), 9.35(\mathrm{~s}, 1 \mathrm{H}), 8.24-8.26(\mathrm{~m}, 1 \mathrm{H})$, 7.67-7.73 (t, J = $7 \mathrm{~Hz}, 1 \mathrm{H}), 7.38-7.43(\mathrm{~m}, 3 \mathrm{H}), 6.94-6.99(\mathrm{~m}$, $1 \mathrm{H}), 6.87(\mathrm{~d}, \mathrm{~J}=8 \mathrm{~Hz}, 2 \mathrm{H}), 3.71(\mathrm{~s}, 3 \mathrm{H}) ;{ }^{13} \mathrm{C} N M R(400 \mathrm{MHz}$, DMSO- $\left.\mathrm{d}_{6}\right) \delta 154.9,153.0,152.3,146.8,138.5,132.0,120.6$, 117.3, 114.1, 111.8, 55.2; IR (KBr) $\left(\mathrm{cm}^{-1}\right) 3227(\mathrm{NH}), 1697(\mathrm{C}=$ O); FAB (NBA) $244.1\left(\mathrm{M}^{+}+\mathrm{H}\right)$; HRMS (FAB) calcd for $\mathrm{C}_{13} \mathrm{H}_{13} \mathrm{~N}_{3} \mathrm{O}_{2} 244.1086\left(\mathrm{M}^{+}+\mathrm{H}\right)$, obsd 244.1083.

N-Phenyl-N'-(pyrid-4-yl)urea (11). ${ }^{10 f}$ To a solution of 4-aminopyridine $(4.90 \mathrm{~g}, 52.1 \mathrm{mmol})$ in THF (150 mL) was added phenylisocyanate $(5.77 \mathrm{~mL}, 52.6 \mathrm{mmol})$. After being refluxed for $19 \mathrm{~h}$, the solution was concentrated under reduced pressure to give a crude solid. Recrystallization of the crude solid from methanol gave $\mathbf{1 1}$ as a white solid $(2.53 \mathrm{~g}, 11.9$ mmol, 22\%). mp 180-182 ${ }^{\circ} \mathrm{C}$; ${ }^{1} \mathrm{H}$ NMR (400 MHz, DMSO-d 6 ) $\delta 9.08(\mathrm{~s}, 1 \mathrm{H}), 8.84(\mathrm{~s}, 1 \mathrm{H}), 8.33-8.35(\mathrm{~m}, 2 \mathrm{H}), 7.42-7.47(\mathrm{~m}$, $4 \mathrm{H}), 7.29(\mathrm{t}, \mathrm{J}=8 \mathrm{~Hz}, 2 \mathrm{H}), 7.00(\mathrm{t}, \mathrm{J}=8 \mathrm{~Hz}, 1 \mathrm{H}) ;{ }^{13} \mathrm{C} N M R$ $\left(400 \mathrm{MHz}, \mathrm{DMSO}-\mathrm{d}_{6}\right) \delta 152.1,150.1,146.5,139.1,128.8,122.4$, 118.5, 112.2; IR (KBr) (cm $\left.{ }^{-1}\right) 3345(\mathrm{NH}), 1706(\mathrm{C}=\mathrm{O}) ; \mathrm{FAB}$ (NBA) $214.1\left(\mathrm{M}^{+}+\mathrm{H}\right)$; HRMS (FAB) calcd for $\mathrm{C}_{12} \mathrm{H}_{11} \mathrm{~N}_{3} \mathrm{O}$ $214.0980\left(\mathrm{M}^{+}+\mathrm{H}\right)$, obsd 214.0983.

Acknowledgment. We thank the National Science Council of Republic of China for the financial support (NSC 91-2113-M-002-024).

Supporting Information Available: Evaluation of the binding constant $\mathrm{K}_{\mathrm{B}}$, figures showing the binding experiments of ureas $3,4,5,9,10$, and 13 with various amounts of cytosine, and CIF files for $\mathbf{1 2}$ and $\mathbf{1 3}$. This material is available free of charge via the Internet at http://pubs.acs.org.

\section{J 00355808}

(22) Novikov, E. G. Khim. Geterotsikl. Soedin., Sb. (in Russian) 1968, 1, 115; Chem. Abstr. 1970, 3776. 